\title{
Amylose Quantity Influence on the Wheat Bread Quality Indicators While Storage
}

\author{
Natalia V. Leiberova', Natalya A. Pankratyeva ${ }^{1}$ * \\ ${ }^{1}$ Ural State University of Economics, Ekaterinburg, Russian Federation, *e-mail: nata-pankratyeva@yandex.ru
}

\author{
Keywords: \\ bakery products; \\ starch; \\ retrogradation; \\ amylose; \\ waxy wheat; \\ biochemical processes; \\ shelf life
}

\begin{abstract}
Considering the question of the national security the article concerns the main process aspects of starch retrogradation. There are objectives of the bakery products development of long-term storage. The authors studied modern approaches to the selection of soft wheat for breeding of varieties with low amylose in starch. They revealed the waxy wheat varieties influence on the baking properties and the staling process of bakery products from baking flour experimentally. The researchers used standard methods for determining amylose, wheat gluten in wheat baking flour of grade 1, as well as organoleptic, physical and chemical experimental methods for establishing the bakery products quality during the study. As a result, the use of wheat flour with a low content of amylose has a beneficial effect on slowing the bread staling process and enable the maximum preservation of the original consumer characteristics.
\end{abstract}

\section{Влияние содержания амилозы на показатели качества пшеничного хлеба в процессе хранения}

\author{
Н.В. Лейберова ${ }^{1}$, Н.А. Панкратьева ${ }^{1 *}$ \\ 'уральский государственный экономический университет, г. Екатеринбург, Российская Федерация, \\ *e-mail: nata-pankratyeva@yandex.ru
}

Ключевые слова:
хлебобулочные
изделия;
крахмал;
ретроградация;
амилоза;
пшеница-шаху;
биохимические
процессы;
срок годности

Реферат

Рассмотрена специфика процессов ретроградации крахмала; обоснована необходимость разработки хлебобулочных изделий длительного хранения в свете решения вопросов продовольственной безопасности страны. Изучены современные подходы к селекции мягкой пшеницы с целью выведения сортов с низким содержанием амилозы в крахмале. Опытным путем установлено влияние на хлебопекарные свойства и процесс черствения хлебобулочных изделий, выпеченных из хлебопекарной муки, пшеницы сорта waху. В ходе исследований применялись стандартные методы определения амилозы, пшеничной клейковины в муке пшеничной хлебопекарной первого сорта, а также органолептические и физико-химические методы исследования для установления качественных показателей хлебобулочных изделий. Сделан вывод: использование пшеничной муки с низким содержанием амилозы замедляет процесс черствения хлеба и способствуют максимальному сохранению его первоначальных потребительских характеристик. 


\section{Introduction}

Human consumption of grain cereals and products of its processing has its own history, dating back thousands of years and described in a number of scientific papers. While baking industry improving and forming a man has developed the scientific bakery production technology basis, technological process rational methods and modes, its control and measures to improve the quality of products. However, some baking aspects determined by modern time trends still remain unexplored.

Bakery of long-term storage production is one of the modern baking trends aimed at solving the problem of food security of the country including continual bread supply to the population living in areas with harsh climatic conditions, as well as in crisis and emergency situations. Besides, with the implementation of the Federal law № 446 "On Amendments to Article 5 of the Federal law "On the Agriculture Development" and the Federal law "On the State Regulation Basis of Trade Activities in the Russian Federation" on 28 November 2018 economic entities effecting food sales through the trading network, and economic entities supplying trading networks with food are unable to enter into contracts containing conditions for the return of unsold after a certain period food with the shelf life up to thirty days. It affects the enterprise competitiveness significantly.

Objective: to study the effect of flour with low amylose quantity on the duration of bread storage and its quality indicators.

Research Objects and Methods

The research objects were first grade baking wheat flour, wheat flour obtained from soft white waxy wheat, bakery products. The authors determined the amylose content in wheat flour by photocolorimetric method using the calibration schedule according to the GOST ISO 6647-1-2015 "Fig. Amylose Content Determination. Part 1. Reference Method" on SF-46 spectrophotoelectrocolorimeter. Calibration graph is the dependence of the optical density from the amylose mass fraction in the test samples of flour. To do this, a man treated the skimmed flour with a sodium hydroxide solution, added an iodine solution that formed a colored amylose and iodine complex, and then determined the optical density by the SF-4 spectrophotoelectrocolorimeter at a wavelength of $720 \mathrm{~nm}$.

The authors determined the gluten quantity and quality in wheat flour according to the GOST 278392013 "Wheat Flour. Methods for determining the gluten quantity and quality". After baking and cooling they stored the packed product samples in a thermostat at $37^{\circ} \mathrm{C}$ for 10 days. Packaging material was paper additionally packed in a plastic bag. Quality indicators were checked on the 1, 3, 5, 7 and 10 days.
Research Results and Its Discussion

Nowadays according to the GOST R 56631 - 2015 "Bakery Products from Wheat Baking Flour. General Specifications" implemented in the RF, bakery products of a long-term storage from wheat flour are products with a shelf life of 5 days or more. Howev$\mathrm{er}$, without the additives of various operating principles and the special packaging materials use it is difficult to achieve long shelf life.

While storing bakery products its consumer properties deteriorate: the crumb elasticity and compressibility decreases, its crumbling increases, the taste and flavor become less pronounced. Still, these changes are not the cause, but the consequence of the processes occurring during the bread storage, mainly in carbohydrates and proteins.

In the bread baking process starch gelatinized partially, absorbing the water released by coagulated protein substances. As a result, the starch passes from the initial crystalline to the amorphous state. At the same time, it absorbs a significant amount of water released by coagulated proteins in the dough while baking bread $[1 ; 3]$. When storing baked bread, the starch in its crumb goes under the retrogradation, i.e. the partial reverse transition of the starch to the crystalline state similar to the starch state in the dough before baking. In this case, the structure of the starch gets thicker. Its solubility decreases. And there is a partial release of moisture absorbed during gelatinization.

Starch granules consist of two types of molecules - amylose and amylopectin. The amylose amount in wheat ranges from 20 to $25 \%$, the amylopectin amount - from 75 to $80 \%$. At the same time, in the higher grades of wheat flour there is more starch c than in the lower ones. This is due to the nonequilibrium distribution of starch and protein in the grain endosperm and the technological process peculiarities of grain processing into flour. Swelling is going with hydration of amylose and amylopectin macromolecules, weakening and destruction of hydrogen bonds between them. Amylose builds hydrated micelles in hot water, but it retrogrades (precipitates) eventually in the form of insoluble gel [6]. There are several stages of amylose retrogradation. At first, randomly twisted spirals of amylose chains are stretched. After that they lose the hydrate shell and settle down one by one. There are hydrogen bonds between hydroxyl groups located at a close distance. Thus, a large number of molecules binding leads to the visible flake occurrence. Retrogradation is due to the starch polysaccharides instability, especially amylose, in the solution. Amylopectin retrogrades more slowly and to a lesser extent than amylose [7].

The increase in temperature slows down the retrogradation process. The starch concentration 
boosts this process. The higher the viscosity, the stronger the retrograde [2].

One of the effective means of bread and bakery products quality improvement as well as staling process slowing is the use of bakery wheat flour waxy varieties in recipes combining three inactive zero allele, which leads to a complete blocking of the enzyme GZ (grain-bound starch-synthase) and amylose synthesis. In this case, the starch consists only of amylopectin. Wheat with one or two zero alleles has a partially blocked amylose synthesis and is called partial-waxy [4].

The water absorption in wheat flour baking and wheat-wax mixtures is as much as the percentage of wax wheat flour additives is higher. Increasing the water absorption capacity of flour provides bread stuffing, increasing the weight yield of the product. And more active amylolysis improves the baked bread volume $[4 ; 5]$.

The flour obtained from waxy varieties of wheat in pure form is not suitable for baking bakery products. Bread obtained from such flour has a low specific volume, and sticky crumb structure. This is due to the decline in the bread quality for a rather important figure as the "falling number" or Hagberg number. This figure In waxy wheat ranges from 67 to $80 \mathrm{sec}$, that is quite low. For soft wheat varieties "falling number" is in the range of 350 and $400 \mathrm{sec}$. [5]. Accordingly, with a decrease in the viscosity index and amylase, there is an increase in the amylolytic enzymes activity of mature wheat grain.

Researchers run the following studies during the recipe development of the bakery products with an increased shelf life:

- studying of baking wheat flour samples for the amylose amount;

- modeling of bakery products recipes from wheat flour with different amylose amount;

- revealing of shelf life of the developed bakery product, considering traditional consumer characteristics compliance.

Data on the amylose effect on the overall wheat bread crumb deformation (compressibility) during storage are presented in table 1.
According to the table 1 , products made from wheat flour with a low content of amylose (sample number 4) characterized by the smallest changes in the overall deformation. Traditionally, bread is identified as stale with a decrease in crumb deformation by 40 percent or more. The study results show that the total deformation of the crumb did not reach $40 \%$ even on the 10 th day of bread storage.

The different gluten amount in the flour also effects the staling process of the bakery product confirmed by the literary sources [9; 10]. The staling rate is inversely related to the protein amount in the flour [10]. The specific products volume largely depends on the protein amount. In this case, the largest volume had products baked from flour with a higher gluten amount.

The figure displays the change in the quality of the bakery product sample № 4 during storage.
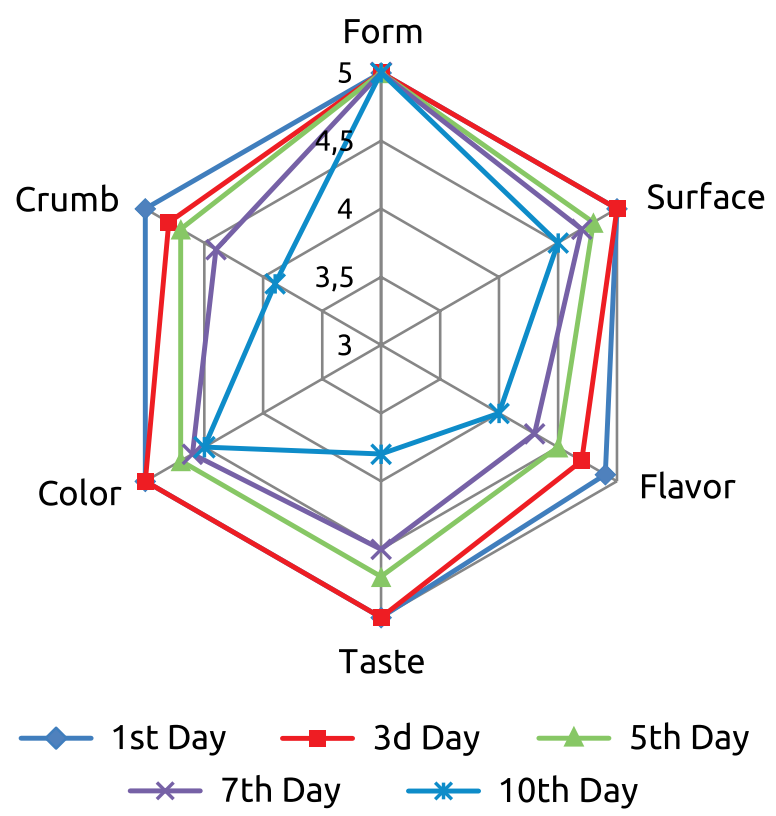

Profilogram of Changes in Quality Indicators during the Storage of Bread Baked from Flour with a Low Amylose Amount

Профилограмма изменения показателей качества в прочессе хранения хлеба, выпеченного из муки с низким содержанием амилозы

Table 1. General Deformation of Wheat Bread Crumb Obtained from Flour with Different Amylose Amount during Storage Таблица 1. Общая деформация мякиша пшеничного хлеба в процессе хранения, полученного из муки с различным содержанием амилозы

\begin{tabular}{|c|c|c|c|c|c|c|c|}
\hline $\begin{array}{c}\text { Sample number, } \\
\text { № }\end{array}$ & $\begin{array}{c}\text { Gluten Mass Fraction } \\
\text { in the Flour, } \\
\text { \%/ Quality Group }\end{array}$ & $\begin{array}{c}\text { Amylase Content } \\
\text { in flour, \% }\end{array}$ & \multicolumn{3}{|c|}{ Total Crumb Deformation (compressibility) } \\
\hline № 1 & 32,1/I group & 26,0 & 14,23 & 10,21 & 3,14 & 3,10 & 2,87 \\
\hline № 2 & 32,7/I group & 20,0 & 13,97 & 10,01 & 2,98 & 2,90 & 2,87 \\
\hline № 3 & 35,3/I group & 16,0 & 13,87 & 11,12 & 5,40 & 5,11 & 4,76 \\
\hline № 4 & 34,6/ I group & 10,0 & 14,3 & 12,2 & 9,21 & 9,01 & 8,74 \\
\hline
\end{tabular}


Table 2. Organoleptic, Physical and Chemical Parameters of Wheat Flour Bread with $10 \%$ of Amylose Amount Таблица 2. Органолептические и физико-химические показатели хлеба из пшеничной муки с $10 \%-м$ содержанием амилозы

\section{Indicator}

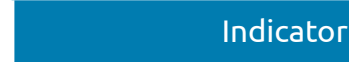

\section{Cowberry Pectin}

\section{Organoleptic Indicator}

\section{Appearance:}

Form

Surface

Color

Crumb:

Soak

Porosity

Taste and Flavor

\section{Correct, Corresponding to the Molded Bread Rectangular Form}

Smooth, Pure, without Explosions

Light Brown
Soaked Crumb, not Moist by Touch, Formable

Well Developed, Pores of Medium Size, Evenly Distributed throughout the Product Volume, without Cavity and Impurity Traces

Pleasant Smell Peculiar to Wheat Bread, without Foreign Flavor and Taste

Physical and Chemical Parameters
42,5

3,5

72,0
The figure proves that the quality characteristics of the product change during the storage. The main changes are within indicators such as taste and flavor, and the crumb state.

The table 2 shows the organoleptic, physical and chemical parameters of wheat flour bread with a low amylose amount for the10th day of the storage.

In the case of researches including laboratory baking, authors revealed that reducing the amylose amount in starch impacted directly on the freshness preservation. Products in the storage process retain its original organoleptic properties longer: elastic, not crumbly crumb, pleasant flavor and taste typical of wheat bread.

\section{Conclusion}

Thus, one of the technological solutions for the bakery production of long-term storage is the use of flour with a low amylose and sufficient gluten protein amount. The study requires continuation in order to establish the technological parameters of the dough preparation by sponge and non-sponge method, recipes of bakery products from wheat baking flour with different amylose and protein amount.

\section{Bibliography}

1. Auerman, L.Ya. Tekhnologiya Hlebopekarnogo Proizvodstva [Technology of Bakery Production]. M.: Legkaya i Pishch. Prom-st, 1984. P. 416.

2. Kazakov, E.D.; Karpilenko, G.P. Biohimiya Zerna i Hleboproduktov [Biochemistry of Grain and Bread Products]. SPb.: GIORD, 2005. P. 512.

3. Pashchenko, L.P.; Zharkova, I.M. Processy, Protekayushchie v Hlebe pri Cherstvenii [Processes Occurring in Bread when Staling]. Tekhnologiya Hlebopekarnogo Proizvodstva: Uchebnik. Spb.: Izd-vo «Lan», 2014. P. 672.

4. Ryzhkova, T.A.; Tretyakov, M.Yu.; Necvetaev, V.P. i dr. Geny WX i Reologicheskie Svojstva Shrota Myagkoj Pshenicy [WX Genes and Rheological Properties of Soft Wheat Meal] // Nauchnye Vedomosti Belgorodskogo Gosudarstvennogo Universiteta. Ser.: Estestvennye Nauki. 2012. № 15(134), vyp.20. P. 46-50.

\section{Библиографический список}

1. Ауэрман Л.Я. Технология хлебопекарного производства. М.: Легкая и пищ. пром-сть, 1984. 416с.

2. Казаков Е.Д., Карпиленко Г.П. Биохимия зерна и хлебопродуктов. СПб.: ГИОРД, 2005. 512с.

3. Пащенко Л.П., Жаркова И.М. Процессы, протекающие в хлебе при черствении. Технология хлебопекарного производства: учебник. СПб.: Изд-во «Лань», 2014. 672 с.

4. Рыжкова Т.А., Третьяков М.Ю., Нецветаев В.П. и др. Гены wх и реологические свойства шрота мягкой пшеницы // Научные ведомости Белгородского государственного университета. Сер.: Естественные науки. 2012. № 15(134), вып. 20. С. 46-50.

5. Панкратьева Н.А., Заворохина Н.В., Школьникова М.Н., Селиванов Н.И., Чепелев Н.И. Разработка рецептур мучных изделий с увеличенным сроком хранения и повышенной пищевой ценностью // Вестник Красноярского государственного аграрного университета. 2018. № 4 (139). С. 191-196. 
5. Pankratyeva, N.A.; Zavorohina, N.V.; Shkolnikova, M.N.; Selivanov, N.I.; Chepelev, N.I. Razrabotka Receptur Muchnyh Izdeliy s Uvelichennym Srokom Hraneniya i Povyshennoj Pishchevoj Cennostyu [Recipes Development of Flour Products with Increased Shelf Life and Nutritional Value] // Vestnik Krasnoyarskogo Gosudarstvennogo Agrarnogo Universiteta. 2018. № 4 (139). P. 191-196.

6. Halikov, R.M.; Nigamatullina, G.B. Transformaciya Makromolekul Amilozy i Amilopektina pri Tekhnologicheskoj Pererabotke Krahmalnyh Granul Rastitelnogo Syrya v Pishchevoj Industrii [Macromolecules, Amylose and Amylopectin Transformation during Technological Starch Granules Processing of Vegetable Raw Materials in the Food Industry] // Nauka-rastudent.ru. 2015. № 01(013-2015). URL: http:// nauka-rastudent.ru. /13/2315/

7. Starch J.J. Structur and properties // Chemical and Functional Properties of Food Saccharides. London: CRC Press, 2004. Pp. 81-101.

8. Hayakawa K., Tanaka K., Nakamura T., et al. Quality characteristics of waxy hexaploid wheat (Triticum aestivum L.): properties of starch gelatinization and retrogradation // Cereal Chemistry. 1997. Vol.74, No. 5. Pp. 576-580.

9. Hayakawa K., Tanaka K., Nakamura T., et al. End use quality of waxy wheat flour in various grain - based foods // Cereal Chemistry. 2004. Vol. 81, No. 5. Pp. 666-672.

10. Ribotta P.D., Ausar S.F., Beltrano D.M., et al. Interactions of hydrocolloids and sonicated-gluten protein // Food Hydrocolloids. 2005. No. 19. P. 93.
6. Халиков Р.М., Нигаматуллина Г.Б. Трансформация макромолекул амилозы и амилопектина при технологической переработке крахмальных гранул растительного сырья в пищевой индустрии // Nauka-rastudent.ru. 2015. № 01(013-2015). URL: http:// nauka-rastudent.ru. /13/2315/

7. Starch J.J. Structur and properties // Chemical and Functional Properties of Food Saccharides. London: CRC Press, 2004. Pp. 81101.

8. Hayakawa K., Tanaka K., Nakamura T., et al. Quality characteristics of waxy hexaploid wheat (Triticum aestivum L.): properties of starch gelatinization and retrogradation // Cereal Chemistry. 1997. Vol.74, No. 5. Pp. 576-580.

9. Hayakawa K., Tanaka K., Nakamura T., et al. End use quality of waxy wheat flour in various grain - based foods // Cereal Chemistry. 2004. Vol. 81, No. 5. Pp. 666-672.

10. Ribotta P.D., Ausar S.F., Beltrano D.M., et al. Interactions of hydrocolloids and sonicated-gluten protein // Food Hydrocolloids. 2005. No. 19. P. 93.

\section{Информация 06 авторах / Information about Authors}

\section{Leiberova, Natalia Viktorovna \\ Лейберова Наталия Викторовна}

Тел./Phone: +7 (343) 221-17-22

E-mail: nleyberova@mail.ru
Candidate of Technical Science, Associate Professor of the Merchandise and Expertise Department

Ural State University of Economics 620144, Russian Federation, Ekaterinburg, 8 March St. / Narodnoy Voli St., 62/45

Кандидат технических наук, доцент кафедры товароведения и экспертизы Уральский государственный экономический университет 620144, Российская Федерация, г. Екатеринбург, ул. 8 Марта/Народной Воли, 62/45

\section{Pankratyeva, Natalya Anatolyevna \\ Панкратьева Наталья Анатольевна}

тел./Phone: +7 (343) 221-17-26

E-mail:nata-pankratyeva@yandex.ru
Senior Lecturer of the Food Engineering Department Ural State University of Economics 620144, Russian Federation, Ekaterinburg, 8 March St. / Narodnoy Voli St., 62/45

Старший преподаватель кафедры технологии питания Уральский государственный экономический университет 620144, Российская Федерация, г. Екатеринбург, ул. 8 Марта/Народной Воли, 62/45 